\title{
Sympathetic Voltage-Independent Regulation of Voltage- Gated Calcium Channels in Pancreatic $\beta$-Cells
}

\author{
Lizbeth de la Cruz, Arturo Reyes-Vaca, Julieta Garduño, Isabel Arenas and David E. Garcia* \\ Department of Physiology, School of Medicine, Universidad Nacional Autonóma de México (UNAM), Apartado Postal \\ 70250, C.P. 04510 México, CdMx, México.
}

\begin{abstract}
Received: December 30, 2017; Accepted: January 27, 2018; Published: February 02, 2018
*Corresponding author: David E. García, Department of Physiology, School of Medicine, Universidad Nacional Autónoma de México (UNAM),

Apartado Postal 70250, C.P. 04510 México, CdMx, México. Tel: +52 155 5623-2137; E-mail: erasmo@unam.mx
\end{abstract}

\begin{abstract}
Voltage-gated calcium $\left(\mathrm{Ca}_{V}\right)$ channels are regulated by G proteins via voltage-dependent and independent pathways. Voltage-independent regulation of calcium channels is important for intracellular calcium concentration and insulin secretion. Voltage dependence of each pathway can be elucidated by a prepulse facilitation protocol. Using this experimental approach, we compared $\mathrm{Ca}_{\mathrm{v}}$ regulation by GTP $\gamma \mathrm{S}$ and noradrenaline (NA) in rat pancreatic $\beta$-cells and rat superior cervical ganglion (SCG) neurons. The SCG neuron is a model in which the bases of $\mathrm{Ca}_{v}$ channel regulation by $\mathrm{G}$ proteins have been established. $\mathrm{Ca}_{V}$ channel regulation through activation of the sympathetic nervous system has been poorly studied in native insulin-secreting cells. We recorded $\mathrm{Ca}_{\mathrm{v}}$ channel currents by means of the patch-clamp technique in the whole-cell configuration. We found that application of both GTP $\gamma$ S (a nonspecific activator of G proteins) by cell dialysis and noradrenaline (NA)-exposure reduced Ca $\mathrm{V}_{\mathrm{V}}$ current amplitude in pancreatic $\beta$-cells and in SCG neurons. However, the inhibition of $\mathrm{Ca}_{\mathrm{v}}$ channel currents in GTP $\gamma \mathrm{S}$-dialyzed SCG neurons was relieved by a strong depolarizing pulse. By contrast, in pancreatic $\beta$-cells, the inhibition was maintained after a strong depolarizing pulse. In SCG neurons, the $\mathrm{Ca}_{v}$ channel inhibition by NA is predominantly voltage-dependent, whereas in pancreatic $\beta$-cells it is only $40 \%$. Thus, it appears that Ca $\mathrm{a}_{v}$ channels in rat pancreatic $\beta$-cells are regulated mainly through a voltage-independent pathway. The signaling pathway for $\mathrm{Ca}_{V}$ channel regulation by NA in pancreatic $\beta$-cells appears to differ from the classic signaling pathway described in SCG neurons. Therefore, voltage-independent regulation of $\mathrm{Ca}^{2+}$ entry through $\mathrm{Ca}_{v}$ channels is a critical step in understanding the pathophysiology of type 2 diabetes.
\end{abstract}

Keywords: G proteins; pancreatic $\beta$-cell; voltage-dependent calcium channel; voltage-dependent pathway; voltage-independent pathway.

\section{Introduction}

The islets of Langerhans are innervated by the sympathetic nervous system $[1,16]$. Secretion of insulin by cells in these islets is inhibited by the neurotransmitter noradrenaline (NA) through activation of $\alpha 2$-adrenergic receptors coupled to $G$ proteins $[1,19]$. NA has been shown to regulate voltage-gated calcium $\left(\mathrm{Ca}_{\mathrm{v}}\right)$ channels in insulin-secreting cell lines, however, this has not been observed in native pancreatic $\beta$-cells $[3,13,19]$.

$\mathrm{G}$ protein regulation of $\mathrm{Ca}_{V}$ channels has been studied extensively in neurons of the superior cervical ganglion (SCG), and the biophysical properties of $\mathrm{Ca}_{\mathrm{V}}$ channels are differentially expressed via voltage-dependent and -independent pathways $[11,20]$. Both pathways reduce the $\mathrm{Ca}_{\mathrm{V}}$ channel current amplitude and regulate $\mathrm{Ca}^{2+}$-dependent processes, such as neurotransmitter release. NA-induced inhibition of $\mathrm{Ca}_{V}$ channels in neurons is a fast voltage-dependent mechanism [6]. The voltage-dependent pathway is thought to be delimited to the plasma membrane by $G$ protein $\beta \gamma$ subunits; the voltageindependent pathway is less understood. There is evidence that the membrane lipid $\mathrm{PIP}_{2}$ is the molecule responsible for the voltage-independent inhibition of $\mathrm{Ca}_{V}$ channels triggered by $\mathrm{M}_{1} \mathrm{R}$ activation [9,10,15]. Furthermore, some other voltageindependent pathways have been documented [20].
Voltage-independent regulation of calcium channels governs intracellular calcium concentration and insulin secretion. The voltage-dependent and -independent pathways can be elucidated by a prepulse protocol that consists of two identical voltage pulses separated by a strong depolarizing pulse [8]. The strong depolarizing pulse is commonly used as a tool to differentiate the two mechanisms. It can be mimicked by action potential burst firing and thus it is physiologically relevant to study the voltage-dependence of $\mathrm{Ca}_{V}$ channel regulation [4,17].

Pancreatic $\beta$-cells and SCG neurons express $\alpha 2$-adrenergic receptors, therefore, we examined $\mathrm{NA}$ regulation of $\mathrm{Ca}_{V}$ channels. We used rat SCG neurons, a model in which signaling pathways have been elucidated, so that we could compare NA regulation of $\mathrm{Ca}_{V}$ channels in pancreatic $\beta$-cells against NA regulation of $\mathrm{Ca}_{V}$ channels in SCG neurons. In order to compare $\mathrm{G}$ protein regulation in both cell types, endogenous $\mathrm{G}$ proteins were activated with GTP $\gamma \mathrm{S}$. A prepulse protocol was used to isolate the voltage-dependent and -independent pathways.

\section{Materials and Methods}

\section{Cell Culture}

Wistar rats were provided by the Universidad 
Nacional Autonóma de México School of Medicine's animal breeding facility and were handled according to the Mexican Official Norm for Use, Care and Reproduction of Laboratory Animals (NOM-062-ZOO-1999).

Neurons were dissociated from the SCG by mechanical and enzymatic methods, as previously described [14]. Pancreatic $\beta$ cells were also obtained as previously described [5]. SCG neurons and pancreatic $\beta$-cells were plated and incubated at $37^{\circ}$ $\mathrm{C}$ in a humidified atmosphere of $95 \%$ air and $5 \% \mathrm{CO}_{2}$ for $16-24$ hours before electrophysiological recordings.

\section{Electrophysiological study}

Recordings of $\mathrm{Ca}_{\mathrm{V}}$ currents in SCG neurons and pancreatic $\beta$ cells were obtained at room temperature $\left(22-24^{\circ} \mathrm{C}\right)$ by the patch-clamp technique in the whole-cell configuration and using an EPC-9 amplifier (HEKA Electronic, Lambrecht, Germany). Voltage protocols were generated, and current responses were digitized and stored by means of the Patchmaster software (HEKA Electronic). Pipettes were pulled from borosilicate glass capillaries with a horizontal patch electrode puller (Sutter Instrument, Novato, CA, USA), and SCG neurons were filled with internal solution consisting of (in $\mathrm{mM}$ ) $140 \mathrm{CsCl}, 20$ TEA-Cl, 10 HEPES, 0.1 BAPTA-tetra cesium, $5 \mathrm{MgCl}_{2}, 5 \mathrm{Na}_{2} \mathrm{ATP}, 0.3 \mathrm{Na}_{2} \mathrm{GTP}$, and 0.1 leupeptin; the solution was adjusted to $\mathrm{pH} 7.2$ with $\mathrm{CsOH}$. Resistance of the pipettes was 1.8-2.0 M $\Omega$. Pancreatic $\beta$ cells were filled with internal solution consisting of (in mM) 140 CsCl, 32 TEA-Cl, 10 HEPES, 0.1 BAPTA-4 Cs, $1 \mathrm{MgCl}_{2}$, $3 \mathrm{Na}_{2} \mathrm{ATP}, 3$ $\mathrm{Na}_{2} \mathrm{GTP}$, and 0.1 leupetine; the solution was adjusted to $\mathrm{pH} 7.4$ with $\mathrm{CsOH}$. Resistance of the pipettes was 2.5-3.5 M $\Omega$.

SCG neurons and pancreatic $\beta$-cells were superfused (1-2 $\mathrm{mL} / \mathrm{min}$ ) with external solution designed to isolate $\mathrm{Ba}^{2+}$ currents $\left(\mathrm{I}_{\mathrm{Ba}}\right)$ through $\mathrm{Ca}_{\mathrm{V}}$ channels. For SCG neurons, this solution consisted of (in mM) 165 TEA-Cl, $2 \mathrm{BaCl}_{2}$, 10 HEPES, 8 glucose, 1 $\mathrm{MgCl}_{2}$, and 0.0002 TTX; the solution was adjusted to $\mathrm{pH} 7.4$ with TEA-OH. For pancreatic $\beta$-cells, this solution consisted of (in mM) $125 \mathrm{NaCl}, 5 \mathrm{MgCl}_{2}$, 10 HEPES, 10 glucose, $10 \mathrm{BaCl}_{2}, 2 \mathrm{H}_{2} \mathrm{O}$, and 0.0001 TTX, the solution was adjusted to $\mathrm{pH} 7.4$ with $\mathrm{NaOH}$. Series resistance was compensated to $>70 \%$ and did not exceed $10 \mathrm{M} \Omega$; capacitance of SCG neurons was $60-80 \mathrm{pF}$, and that of pancreatic $\beta$-cells was 6-10 pF. Steady-state currents were sampled at $20 \mathrm{kHz}$. Current recordings were filtered at $2.9 \mathrm{kHz}$.

RPMI medium and Antibiotic-Anti mycotic (100x) were obtained from Life Technologies (Grand Island, NY, USA), bovine serum albumin was obtained from Microlab (México City, México), and all other reagents used were obtained from Sigma (St. Louis, MO, USA).

\section{Data Analysis}

Inhibition of the current induced by GTP $\gamma \mathrm{S}$ or NA was calculated as the amplitude of the steady-state current under GTP $\gamma$ S dialysis or during NA exposure minus the current amplitude under control conditions. Thereafter, it was divided by the current amplitude under control conditions (thus reported as a percentage). The facilitation index was calculated by measuring the peak current amplitude at P2 divided by the peak current amplitude at P1. Time constants $(\tau)$ were calculated from an exponential equation. Data are shown as mean \pm SEM.
Statistical differences were analyzed by t-test. $P<0.05$ was considered significant.

\section{Results}

\section{Inhibition of $\mathrm{Ca}_{V}$ Current by GTP $\gamma \mathrm{S}$}

We first examined the fraction of voltage-dependent and independent regulation by activation of endogenous $\mathrm{G}$ proteins with GTP $\gamma$ S. Although both types of regulation were seen in SCG neurons, the voltage-dependent pathway was predominant under $\mathrm{G}$ protein activation [7]. Representative $\mathrm{Ca}_{\mathrm{V}}$ currents evoked by the prepulse protocol in control and in GTP $\gamma \mathrm{S}$-dialyzed SCG neurons and in pancreatic $\beta$-cells are shown in Figure $1 \mathrm{~A}$ and $\mathrm{B}$, respectively. The $\mathrm{Ca}_{V}$ current amplitude was reduced by GTP $\gamma \mathrm{S}$ in both cell types, however, this inhibition was released after a strong depolarizing pulse only in SCG neurons (Figure 1A and B). In SCG neurons the time course of the reduction in $\mathrm{Ca}_{\mathrm{V}}$ current amplitude by GTP $\gamma \mathrm{S}$ was biphasic (Figure $1 \mathrm{C}$; $\tau 1=17.2 \pm 8.8$ seconds and $\tau 2=29.9 \pm 6.09$ seconds), whereas in pancreatic $\beta$ cells it was monophasic (Figure 1D; $\tau=31.2 \pm 2.6$ seconds). $\mathrm{Ca}_{\mathrm{V}}$ current inhibition was greater in SCG neurons (P1 $=88 \pm 2.3 \%$ and $\mathrm{P} 2=28 \pm 4.3 \%$ ) than in pancreatic $\beta$-cells $(\mathrm{P} 1=53 \pm 4.6 \%$ and $\mathrm{P} 2=50 \pm 5.6 \%$ ) (Figure $1 \mathrm{E}$ ). The facilitation index was used to evaluate the fraction of voltage-dependent and voltageindependent regulation. Facilitation indices in SCG cells were 1.08 \pm 0.06 (control) and $2.82 \pm 0.026(\mathrm{GTP} \gamma \mathrm{S})$, whereas in pancreatic $\beta$-cells, they were $1.04 \pm 0.01$ and $0.99 \pm 0.042$, respectively. In summary, these data support that $\mathrm{Ca}_{V}$ currents are reduced by endogenous $\mathrm{G}$ protein activation. However, voltage-dependent regulation is predominant in rat SCG neurons, whereas voltageindependent regulation does the same in rat pancreatic $\beta$-cells

\section{Voltage-Independent Inhibition of $\mathrm{Ca}_{v}$ Current by NA in Pancreatic $\beta$-Cells}

$\mathrm{Ca}_{V}$ current in sympathetic neurons has been shown to be reduced by NA mainly through a voltage-dependent pathway [6]. Thus, we hypothesized that $\mathrm{Ca}_{\mathrm{v}}$ currents in rat pancreatic $\beta$-cells are regulated by NA in a similar manner. We showed recently that $\mathrm{Ca}_{V}$ channels are regulated in SCG neurons and pancreatic $\beta$-cells via similar pathways when $\mathrm{M}_{1} \mathrm{R}$ is activated. We used a prepulse protocol and characterized a specific time course as a hallmark of a voltage-dependent pathway. Representative P1 and P2 Cav current traces elicited in control and NA-treated sympathetic neurons and pancreatic $\beta$-cells are shown in Figure $2 \mathrm{~A}$ and $\mathrm{B}$, respectively. $\mathrm{Ca}_{\mathrm{V}}$ current was reduced by NA in both cells types, however, the current inhibition was released by the prepulse only in sympathetic neurons. The time course of $\mathrm{I}_{\mathrm{Ba}}$ amplitude in NA-treated sympathetic neurons and pancreatic $\beta$ cells is shown in Figure 2C and D, respectively. Notably, there was a reduction in $\mathrm{Ca}_{\mathrm{V}}$ current amplitude in treated SCG neurons $(87 \pm$ $8.8 \%$ in $\mathrm{P} 1$ and $25 \pm 3.5 \%$ in $\mathrm{P} 2$ ) and treated pancreatic $\beta$-cells $(44.7 \pm 4 \%$ in $\mathrm{P} 1$ and $34.5 \pm 4.4 \%$ in $\mathrm{P} 2)$ (Figure 2$)$. However, the reduced current was scarcely restored by a depolarizing prepulse in pancreatic $\beta$-cells compared to SCG neurons (Figure 2F: SCG control $=1.1 \pm 0.06$, SCG NA $=2.6 \pm 0.42$ and pancreatic $\beta$ control $=$ $1.02 \pm 0.02$, pancreatic $\beta \mathrm{NA}=1.4 \pm 0.03$ cells). Taking together, these data show that $\mathrm{NA}$ reduces the $\mathrm{Ca}_{V}$ current amplitude in 
A
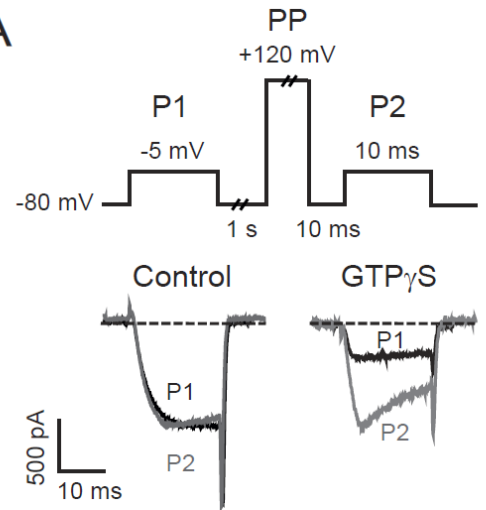

C

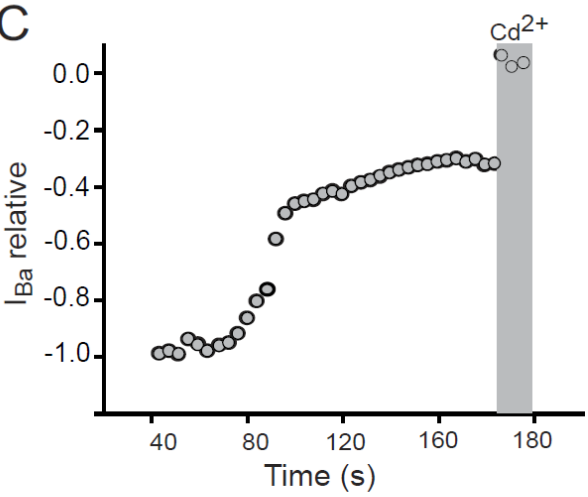

E

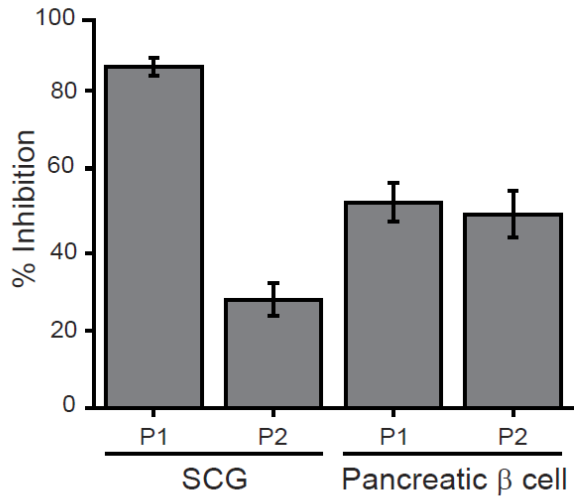

B

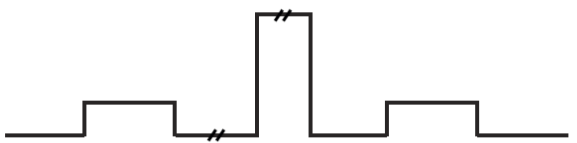

Control

GTP $\gamma$ S

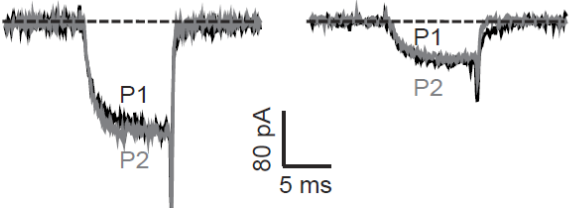

D

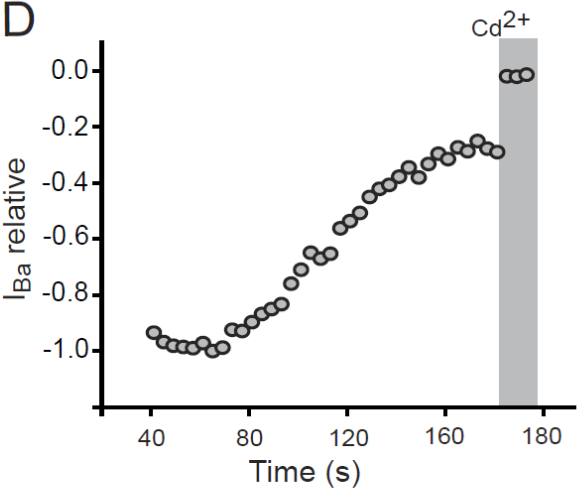

$\mathrm{F}$

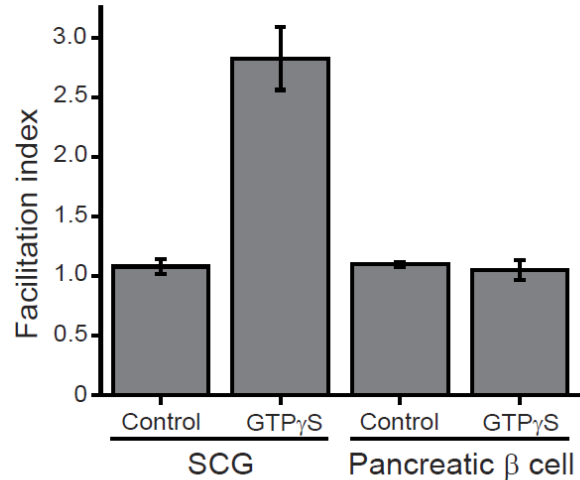

Figure 1: Inhibition of $\mathrm{Ca}_{v}$ current amplitude by GTP $\gamma \mathrm{S}$ via a voltage-independent pathway in rat pancreatic $\beta$-cells. (A) and (B) Representative current traces elicited by a prepulse protocol, which consisted of a pair of $10-\mathrm{ms}$ depolarizing pulses to $-5 \mathrm{mV}$ (P1, P2) from a holding potential of -80 $\mathrm{mV}$ and separation of P1 and P1 by a prepulse (PP) of $+125 \mathrm{mV}$ during a 25 -ms period. Left panel shows overlapping P1 and P2 current traces from rat superior cervical ganglion (SCG) neurons under control and GTP $\gamma \mathrm{S}$ conditions. Right panel shows overlapping P1 and P2 current traces from rat pancreatic $\beta$-cells under control and noradrenaline (NA)-treatment. Time course of $\mathrm{I}_{\mathrm{Ba}}$ relative (P1) in a GTP $\gamma \mathrm{S}$-dialyzed neuron (C) and a pancreatic $\beta$-cell (D). Summary of the percentage inhibition of P1 and P2 (E) and facilitation index (F) in rat SCG neurons and rat pancreatic $\beta$-cells.

rat pancreatic $\beta$-cells through a voltage-independent pathway and suggest that this $\mathrm{Ca}_{V}$ current regulation by NA is significantly different from that observed in SCG neurons.

\section{Discussion}

We showed in rat pancreatic $\beta$-cells that $\mathrm{Ca}_{\mathrm{V}}$ channels are inhibited by $\mathrm{G}$ proteins mainly via voltage-independent pathways. Voltage-independent regulation of calcium channels determines intracellular calcium concentration and insulin secretion. The macroscopic $\mathrm{Ca}_{\mathrm{V}}$ channel current was reduced to $55 \%$ by GTP $\gamma \mathrm{S}$ dialysis. Similarly, in mouse pancreatic $\beta$-cells, GTP $\gamma \mathrm{S}$ dialysis has been shown to reduce $\mathrm{Ca}^{2+}$ currents by $30 \%$ [2]. Inhibition in both mouse and rat pancreatic $\beta$-cells is minimal compared to that in SCG cells. The $\mathrm{Ca}_{\mathrm{V}}$ channel inhibition in the mouse model is partially released by a strong depolarizing pulse, suggesting a predominant voltage-dependent pathway under endogenous $G$ protein activation [2]. 
A

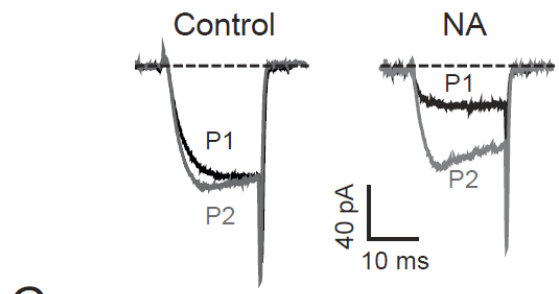

B

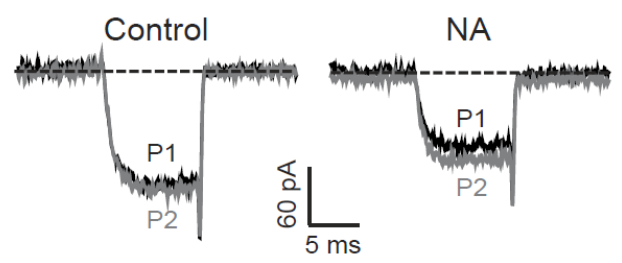

D

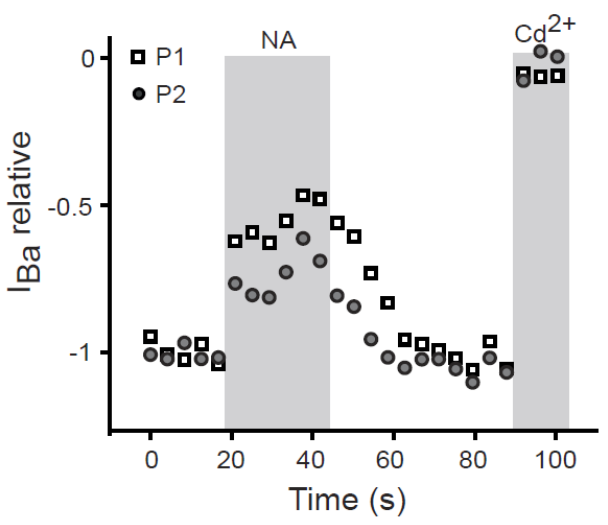

F

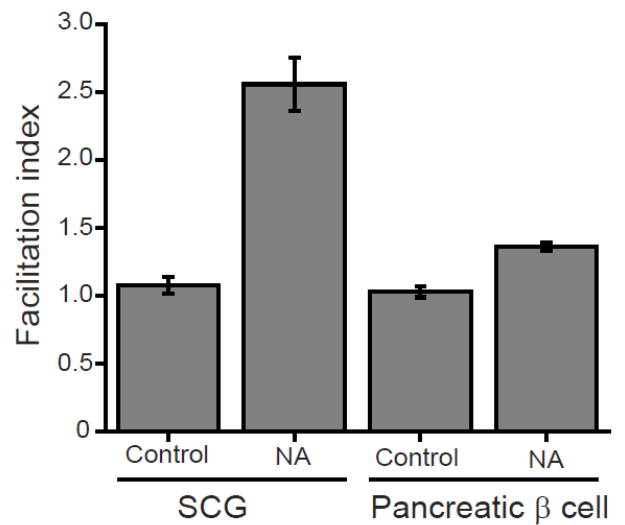

Figure 2: Inhibition of $\mathrm{Ca}_{v}$ current amplitude by(NA)-treatment via a voltage-independent pathway in rat pancreatic $\beta$-cells. (A) and (B) Representative current traces elicited by the prepulse protocol, which consisted of a pair of 10-ms depolarizing pulses to $-5 \mathrm{mV}$ (P1, P2) from a holding potential of $-80 \mathrm{mV}$ and separation of P1 and P1 by a prepulse (PP) of $+125 \mathrm{mV}$ during a 25 -ms period. (A) and (B), overlapping P1 and P2 current traces from $(\mathrm{A})$ rat superior cervical ganglion (SCG) neurons and (B) rat pancreatic $\beta$-cells under control and NA-treatment. Time course of $\mathrm{I}_{\mathrm{Ba}}$ relative (P1) in NA-treated neurons (C) and in pancreatic $\beta$-cells (D). Summary of percentage inhibition of P1 and P2 (E) and facilitation index $(\mathrm{F})$ in rat SCG neurons and rat pancreatic $\beta$-cells.

On the contrary, $\mathrm{Ca}_{\mathrm{v}}$ channel inhibition was not relieved despite the application of a strong depolarizing pulse in GTP $\gamma$ S-dialysed rat pancreatic $\beta$-cells. According to Elmslie and colleagues [8], the voltage-dependent regulation by G proteins in SCG neurons is released by a strong depolarizing pulse, and this relief is the hallmark of $G$ protein regulation in neurons. Our data suggest that regulation of $\mathrm{Ca}_{\mathrm{V}}$ channels by $\mathrm{G}$ protein-coupled receptors in insulin-secreting pancreatic cells could be mediated by pathways that have no relationship to the classic regulatory pathways described in SCG neurons [8].

In SCG neurons, the NA signal is transmitted mainly through $\alpha_{2}$-adrenergic receptors coupled to $\mathrm{Gi}$ proteins. This signaling pathway is voltage-dependent and requires the action of $G \beta \gamma$ subunits $[9,10]$. Similarly, $\alpha_{2}$-adrenergic receptor activation by NA reduces insulin release in rat pancreatic $\beta$-cells $[18,19]$.
$\mathrm{Ca}_{\mathrm{V}}$ channels are thought to be similarly inhibited by activation of $\alpha_{2}$-adrenergic receptors in human $\beta$-, RINm5F, and HIT cells $[13,19]$. The regulation in RINm5F is predominantly voltagedependent, whereas in human $\beta$-cells the inhibition is voltageindependent [13]. Our data suggest that NA inhibits $\mathrm{Ca}_{\mathrm{V}}$ currents via a voltage-independent pathway, in a similar way to human $\beta$-cells. Interestingly, $\alpha_{2}$-adrenoreceptor stimulation does not inhibit L-type calcium channels in mouse pancreatic $\beta$-cells [3]. Our study in primary cultured cells is the very first providing evidence that NA inhibits $\mathrm{Ca}_{V}$ channels in pancreatic $\beta$-cells. The classic understanding is that voltage-independent regulation is mediated by $\mathrm{G}_{\mathrm{q} / 11}$ proteins involving $\mathrm{PIP}_{2}$ hydrolysis, however, there is no evidence that activation of $\alpha_{2}$-adrenergic receptors hydrolyzes $\mathrm{PIP}_{2}$. The signaling cascade and specific 
activities of $G$ protein subunits and their link to $\alpha_{2}$-adrenergic receptors in the modulation of $\beta$-cell $\mathrm{Ca}_{\mathrm{V}}$ channels remain to be elucidated.

Inhibition of the insulin secreting process by activation of the sympathetic nervous system has been reported [18,19]. Our findings are consistent with this notion. We showed that $\mathrm{Ca}_{\mathrm{V}}$ current diminishes in rat pancreatic $\beta$-cells treated with NA, resulting in a decreased $\mathrm{Ca}^{2+}$ entry. Although calcium influx through $\mathrm{Ca}_{\mathrm{V}}$ channels is a known part of this process, little is known about $\mathrm{Ca}_{V}$ channel regulation that occurs via G-protein activation of the voltage-independent pathway. In conclusion, regulation of $\mathrm{Ca}_{V}$ channels by $\mathrm{G}$ proteins in pancreatic $\beta$-cells via a voltage-independent pathway appears to be an additional mechanism by which the $\mathrm{Ca}^{2+}$ concentration is controlled and a key step in such an important physiological process. Whatever the mechanism turns out to be, a voltage-independent mechanism is involved in pancreatic $\beta$-cells. However, an important question for future studies is whether or not a specific voltage-independent mechanism may account for the $\mathrm{Ca}_{V}$ current inhibition in pancreatic $\beta$-cells.

\section{Acknowledgments}

We thank Manuel Hernández and Guillermo Luna for their technical help, Dr. Enrique Pinzón for his excellent care of the rats.

\section{Source(s) of support}

Supported by Programa de Apoyo a Proyectos de Investigación e Innovación Tecnológica (PAPIIT, www.dgapa.unam.mx/html/ papiit/papit.html) IN218016, IA206317 and IV100116, and Consejo Nacional de Ciencia y Tecnología (CONACyT, www.conacyt.gob. mx) 255635 granted to David E. Garcia.

\section{Declarations}

No conflicts of interest, financial or otherwise, are declared by the author(s).

\section{References}

1. Ahren B. Autonomic regulation of islet hormone secretion-implications for health and disease. Diabetologia. 2003;43(4):393410. DOI: $10.1007 / \mathrm{s} 001250051322$.

2. Ammala C, Berggren PO, Bokvist K, Rorsman P. Inhibition of L-type calcium channels by internal GTP [gamma S] in mouse pancreatic beta cells. Pflugers Arch. 1992;420(1):72-77.

3. Bokvist K, Ammala C, Berggren PO, Rorsman P, Wahlander K. Alpha 2-adrenoreceptor stimulation does not inhibit L-type calcium channels in mouse pancreatic beta-cells. Biosci Rep. 1991;11(3):147-157.

4. Brumberg JC, Nowak LG, McCormick DA. Ionic mechanisms underlying repetitive high-frequency burst firing in supragranular cortical neurons. J Neurosci. 2000;20(13):4829-4843.

5. de la Cruz L, Puente EI, Reyes-Vaca A, Arenas I, Garduno J, BravoMartinez J, Garcia DE. PIP2 in pancreatic beta-cells regulates voltagegated calcium channels by a voltage-independent pathway. Am J Physiol Cell Physiol. 2016;311:C630-c640. Doi: 10.1152/ajpcell.00111.2016.
6. Delmas P, Brown DA, Dayrell M, Abogadie FC, Caulfield MP, Buckley NJ. On the role of endogenous G-protein beta gamma subunits in N-type $\mathrm{Ca} 2+$ current inhibition by neurotransmitters in rat sympathetic neurones. J Physiol. 1998;506( Pt 2):319-329.

7. Diaz-Cardenas AF, Arenas I, Garcia DE. PMA counteracts G protein actions on CaV2.2 channels in rat sympathetic neurons. Arch Biochem Biophys. 2008;473(1):1-7. Doi: 10.1016/j.abb.2008.01.030

8. Elmslie KS, Zhou W, Jones SW. LHRH and GTP-gamma-S modify calcium current activation in bullfrog sympathetic neurons. Neuron. 1990;5(1):75-80.

9. Herlitze S, Garcia DE, Mackie K, Hille B, Scheuer T, Catterall WA. Modulation of $\mathrm{Ca} 2+$ channels by G-protein beta gamma subunits. Nature. 1996;380:258-62. Doi: 10.1038/380258a0

10. Ikeda SR. Voltage-dependent modulation of N-type calcium channels by G-protein beta gamma subunits. Nature. 1996;380:255-258. Doi: 10.1038/380255a0

11. Luebke JI, Dunlap K. Sensory neuron N-type calcium currents are inhibited by both voltage-dependent and -independent mechanisms. Pflugers Arch. 1994;428:499-507.

12. Park D, Dunlap K. Dynamic regulation of calcium influx by G-proteins, action potential waveform, and neuronal firing frequency. J Neurosci. 1998;18(17):6757-6766.

13. Pollo A, Lovallo M, Biancardi E, Sher E, Socci C, Carbone E. Sensitivity to dihydropyridines, omega-conotoxin and noradrenaline reveals multiple high-voltage-activated Ca2 + channels in rat insulinoma and human pancreatic beta-cells. Pflugers Arch. 1993;423(5-6):462-471.

14. Reyes-Vaca A, de la Cruz L, Garduno J, Arenas I, Garcia DE. Fast Inactivation of CaV2.2 Channels Is Prevented by the Gbeta1 Subunit in Rat Sympathetic Neurons. J Mol Neurosci. 2017;63:377-384. Doi: 10.1007/s12031-017-0988-8

15. Suh BC, Leal K, Hille B. Modulation of high-voltage activated $\mathrm{Ca}(2+)$ channels by membrane phosphatidylinositol 4,5-bisphosphate. Neuron. 2010;67(2):224-238. Doi: 10.1016/j.neuron.2010.07.001

16. Taborsky GJ, Jr. The physiology of glucagon. J Diabetes Sci Technol. 2010;4:1338-1344. Doi: 10.1177/193229681000400607

17. Tosetti P, Taglietti V, Toselli M. Action-potential-like depolarizations relieve opioid inhibition of N-type Ca2+ channels in NG108-15 cells. Pflugers Arch. 1999;437(3):441-448.

18. Velasco M, Diaz-Garcia CM, Larque C, Hiriart M. Modulation of Ionic Channels and Insulin Secretion by Drugs and Hormones in Pancreatic Beta Cells. Mol Pharmacol. 2016;90(3):341-57. Doi: 10.1124/ mol.116.103861

19. Yang S.N., Berggren P.O. The role of voltage-gated calcium channels in pancreatic beta-cell physiology and pathophysiology. Endocr Rev. 2006;27(6):621-676. Doi: 10.1210/er.2005-0888

20.Zamponi GW, Currie KP. Regulation of $\mathrm{Ca}(\mathrm{V}) 2$ calcium channels by G protein coupled receptors. Biochim Biophys Acta. 2013;1828(7):16291643. Doi: 10.1016/j.bbamem.2012.10.004 